\title{
Clinical profile and cerebrospinal fluid indices in children with complex febrile seizures
}

\author{
Suryavanshi A R. ${ }^{1}$, Bodhgire S B. ${ }^{2 *}$, Anerao R D. ${ }^{3}$, Pawar S. ${ }^{4}$, Patil A T. ${ }^{5}$, Paranjape M. ${ }^{6}$ \\ DOI: https://doi.org/10.17511/ijpr.2020.i06.10 \\ 1 Amol Ramrao Suryavanshi, Associate Professor, Department of Pediatrics, Government Medical College and Hospital, Aurangabad, \\ Maharashtra, India. \\ 2* Sachin Bapurao Bodhgire, Assistant Professor, Health Department, Government Medical College and Hospital, Aurangabad, Maharashtra, \\ India. \\ 3 Rahul Digambarrao Anerao, Incharge, Health Department, District Urban Leprosy, , Maharashtra, India. \\ 4 Shilpa Pawar, Associate Professor, Department of Pediatrics, Government Medical College and Hospital, Aurangabad, Maharashtra, India. \\ 5 Amit Tukaram Patil, Junior Resident, Department of Pediatrics, Government Medical College and Hospital, Aurangabad, Maharashtra, \\ India. \\ 6 Mugdha Paranjape, Junior Resident, Department of Pediatrics, Government Medical College and Hospital, Aurangabad, Maharashtra, India.
}

Introduction: Fever with seizure is the most common type of seizure occurring in children. A seizure is a common presentation for which a child may come to the emergency and may occur in up to $10 \%$ of children presenting to the emergency. Among all these seizures, Febrile seizures (FS) are the most common type of childhood seizures, affecting 2-5\% of children older than 1 month and most commonly from 6 months -5 years old. Material and Methods: A hospital-based, prospective study conducted at the Department of Pediatrics, Government Medical College, and Hospital Aurangabad conducted from November 2018 to February 2020. Results: A total of 120 cases that presented with Complex Febrile Seizures (CFS) between six months to five years of age were included. Among them, 83 (69.1\%) were male and $47(30.9 \%)$ were female children. There were a total of 63 children in 6-12 months age, 32 in 12-24 months, and 25 in the above 12 months age group. Conclusion: In conclusion, it was found that age less than 1 year and male gender were the most significant risk factors for Complex Febrile Seizure in our area.

Keywords: Seizure, Fever, Epilepsy, Complex febrile seizure, clinical profile

\section{Corresponding Author}

Sachin Bapurao Bodhgire, Assistant Professor, Health Department, Government Medical College and Hospital, Aurangabad, Maharashtra, India. Email: sbbodhgire15@gmail.com

\section{How to Cite this Article}

Suryavanshi AR, Bodhgire SB, Anerao RD, Pawar S, Patil AT, Paranjape M. Clinical profile and cerebrospinal fluid indices in children with complex febrile seizures. Pediatric Rev Int J Pediatr Res. 2020;7(6):287-292.

Available From

https://pediatrics.medresearch.in/index.php/ijpr/arti cle/view/617

\section{To Browse}

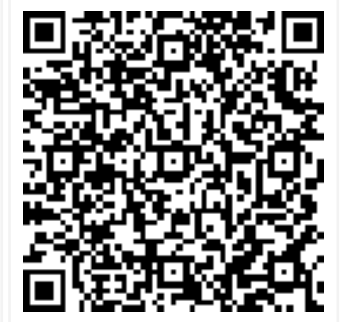

Manuscript Received 2020-08-05

Conflict of Interest No
Review Round 1 2020-08-18

Funding

Nil
Review Round 2 2020-08-24

Ethical Approval Yes
Review Round 3

Plagiarism X-checker $9 \%$
Accepted 2020-08-27

Note

(c) 2020 by Amol Ramrao Suryavanshi, Sachin Bapurao Bodhgire, Rahul Digambarrao Anerao, Shilpa Pawar, Amit Tukaram Patil, Mugdha Paranjape and Published by Siddharth Health Research and Social Welfare Society. This is an Open Access article licensed under a Creative Commons Attribution 4.0 International License https://creativecommons.org/licenses/by/4.0/ unported [CC BY 4.0].

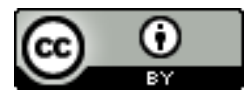




\section{Introduction}

Fever with seizure is the most common type of seizure occurring in children [1]. A seizure is a common presentation for which a child may come to the emergency and may occur in up to $10 \%$ of children presenting to the emergency [2]. Among all these seizures, Febrile seizures (FS) are the most common type of childhood seizures, affecting 2-5\% of children older than 1 month and most commonly from 6 months -5 years old $[3,4]$. The differential diagnosis of febrile seizure includes non-epileptic events or movements, provoked seizures following a central nervous system infection, and rare forms of genetic epilepsy in which seizures typically present with fever.

The preliminary evaluation of children with seizures in the setting of fever must help in distinguishing febrile seizures from other significant and more serious etiologies such as central nervous system infections. Febrile seizures are defined as seizures accompanied by a fever without evidence of intracranial infection, metabolic disturbance, or a history of previous afebrile seizures They are categorized as either simple (generalized, lasting less than 15 minutes and occurring only once in a 24-hour period) or complex (focal seizure, lasting more than 15 minutes or recurrent in a 24-hour period) [5].

It is important to differentiate benign febrile seizures from meningitis early and implement appropriate management. The relationship between seizure and bacterial meningitis has been identified well in the literature. Seizures are the first manifestation of meningitis in $16.7 \%$ of children and in one-third of these patients, whereas meningeal signs and symptoms may not be evident [2]. Some of the literature suggests that in the absence of typical meningeal signs, then an LP should be considered in children with complex seizures, prior antibiotic therapy, age less than 12 months, or incomplete vaccination history.

According to the American Academy of Pediatrics (AAP) guideline, all children with their first febrile seizure under the age of 12 months should have a lumbar puncture (LP) since the signs of meningitis are subtle and also potential risks of delayed treatment of meningitis outweigh any risk of performance of LP $[6,7]$. Hence the performance of lumbar puncture and expectation of normal cerebrospinal fluid (CSF) findings are very much important to differentiate the simple febrile seizures
From other forms of febrile seizures. So CSF indices help in evaluating such children further [8].

In this background, this study was done with the objective to study the clinical feature and cerebrospinal fluid indices in children with complex febrile seizures. This study also highlights the incidence of acute bacterial meningitis (ABM) in children with Febrile Seizures.

\section{Material and Methods}

Study Design: A hospital-based, prospective study.

Study Setting: Department of Pediatrics, Government Medical College, and Hospital Aurangabad.

Duration: November 2018 to February 2020.

Sample Size: 120 cases that were admitted with Complex Febrile Seizure (CFS) during the study period.

Inclusion Criteria: Children aged six months to five years of age admitted with Complex Febrile Seizure (CFS) admitted in Government Medical College and Hospital Aurangabad.

Exclusion Criteria: Children with Simple febrile seizure, who had received antibiotics prior to admission, history of prior neonatal seizures, history of prior afebrile seizure, with known epilepsy, cases with underlying neurological conditions which could lead to seizures such as hydrocephalus, brain tumor, neurocutaneous syndrome or cerebral palsy; seizures as a result of metabolic abnormalities (hypoglycemia or hypocalcemia) and children with absolute systemic and local contraindications for lumbar puncture were excluded from the study.

Data Collection: Detailed demographic and clinical parameters including age, sex, relevant medical history, description, and duration of seizure were evaluated as per standard examination methods. All of the required investigations were performed accordingly. CSF sample collection was done under aseptic conditions in one plain, one fluoride bulb and one BHI broth for CSF protein and chloride, CSF sugar, and CSF culture respectively. The CSF was analyzed as per standard laboratory methods by laboratory technicians. Lumbar puncture was done on the day of admission, and in those with the abnormal result was followed up after 72 hours and after completion of the antibiotic course.

Etiology was finalized based on history, physical 
Examination, and CSF indices. Meningitis was diagnosed in a child presenting with fever and seizure if he/she had a combination of all three of the following: CSF cells $>5 / \mathrm{mm} 3$, protein more than $40 \mathrm{mg} \%$, and sugar $<2 / 3$ of blood sugar [9].

The growth of bacteria in the CSF and/or positive Gram's stain was considered as bacterial meningitis.

Ethical Consideration: The study was approved by the institutional ethical committee. Informed verbal and written consent was taken from the parents or the accompanying adults before performing Lumbar Puncture.

Statistical Analysis: Data were analyzed using SPSS version 16. A Chi-square test was used for statistical analysis and a $\mathrm{p}<0.05$ was considered significant.

\section{Results}

A total of 120 cases that presented with Complex Febrile Seizures (CFS) between six months to five years of age were included. Among them, 83 $(69.1 \%)$ were male and $47(30.9 \%)$ were female children.

There were a total of 63 children in $6-12$ months age, 32 in 12-24 months, and 25 in the above 12 months age group (Table 1 ).

Table 1. Distribution of meningitis in different age groups.

\begin{tabular}{|l|l|l|l|}
\hline Age & $\begin{array}{c}\text { Total no. of children } \\
\text { with complex febrile } \\
\text { seizure(CFS) }\end{array}$ & $\begin{array}{c}\text { Total no children } \\
\text { with impaired } \\
\text { consciousness }\end{array}$ & $\begin{array}{c}\text { Total no. of } \\
\text { children with } \\
\text { meningitis }\end{array}$ \\
\hline $\begin{array}{l}6-12 \\
\text { months }\end{array}$ & 63 & $32(50.7 \%)$ & $12(19 \%)$ \\
\hline $\begin{array}{l}12-24 \\
\text { months }\end{array}$ & 32 & $12(37.5 \%)$ & $6(18.7 \%)$ \\
\hline $\begin{array}{l}24-60 \\
\text { months }\end{array}$ & 25 & $11(44 \%)$ & $5(20 \%)$ \\
\hline Total & 120 & $55(45.8 \%)$ & $23(19.1 \%)$ \\
\hline
\end{tabular}

Chi square value $=0.626$.

Out of a total of 120 cases, 55 (45.8\%) were having impaired consciousness. The majority number of children (12) with meningitis were from 6-12 months of age (19\%). Among all 120 cases of these CFS, 74 children did not have any family history of febrile seizures. Maximum (22) cases with a family history of First degree relatives having febrile seizures were from 6-12 months age group (Table 2).
Table-2: Family history of cases with complex febrile seizures (CFS).

\begin{tabular}{|l|l|l|l|l|}
\hline Age & $\begin{array}{r}\text { First degree } \\
\text { relative with } \\
\text { a history of } \\
\text { FS }\end{array}$ & $\begin{array}{l}\text { Second degree } \\
\text { relative with a third-degree } \\
\text { history of FS }\end{array}$ & $\begin{array}{l}\text { Total children } \\
\text { relative with a } \\
\text { with positive } \\
\text { fistory of FS }\end{array}$ & family history \\
\hline $\begin{array}{l}6-12 \\
\text { months } \\
(\mathrm{n}=63)\end{array}$ & $22(34 \%)$ & $3(4.7 \%)$ & $7(11.1 \%)$ & $32(50.7 \%)$ \\
\hline $\begin{array}{l}13-24 \\
\text { months } \\
(\mathrm{n}=32)\end{array}$ & $5(15 \%)$ & $1(3.1 \%)$ & 0 & $6(18.7 \%)$ \\
\hline $\begin{array}{l}25-60 \\
\text { months } \\
(\mathrm{n}=25)\end{array}$ & $5(20 \%)$ & $2(8 \%)$ & $1(4 \%)$ & $8(32 \%)$ \\
\hline $\begin{array}{l}\text { Total } \\
=120\end{array}$ & $32(26.6 \%)$ & $6(5 \%)$ & $8(6.6 \%)$ & $46(38.3 \%)$ \\
\hline
\end{tabular}

During the study, it was observed that the most common cause attributed to CFS was Upper Respiratory Tract Infection (URTI) in 54 cases (45\%), followed by Meningitis/encephalitis in 23 cases (19.20\%). Whereas Gastroenteritis and pneumonia were the least etiological factor observed $(7.50 \%)$ (Table 4$)$.

Table-3: Causes attributed to complex febrile seizures (CFS).

\begin{tabular}{|l|l|l|}
\hline Cause of complex febrile seizure(CFs) & Number $(n=120)$ & Percentage \\
\hline URTI & 54 & 45 \\
\hline Meningitis /encephalitis & 23 & 19.20 \\
\hline Unknown & 15 & 12.50 \\
\hline UTI & 10 & 8.30 \\
\hline Pneumonia & 9 & 7.50 \\
\hline Gastroenteritis & 9 & 7.50 \\
\hline Total & 120 & 100 \\
\hline
\end{tabular}

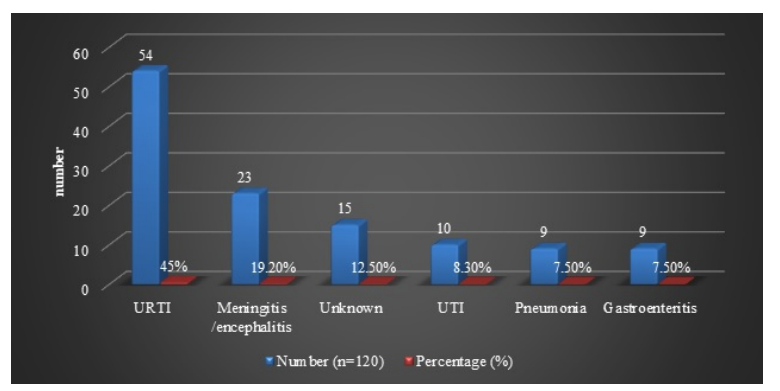

Fig-1: Causes attributed to complex febrile seizures (CFS).

As far as the semiology of these all 120 CFS cases were concerned, 86 were having a generalized tonic-clonic seizure. Among them, in 58 cases it was of more than 15 minutes duration. Focal type of seizure without awake was reported in 22 cases. 
Whereas, 2 cases were having atonic seizures (Table 4).

\section{Table-4: Semiology of complex febrile seizure} (CFS).

\begin{tabular}{|l|l|l|}
\hline \multicolumn{1}{|c|}{ Semi logy } & No. of the patient $(\mathrm{n}=\mathbf{1 2 0})$ & $(\mathrm{\%})$ \\
\hline Generalized tonic clonic $>15$ minute & 58 & 48.30 \\
\hline Generalized tonic $>15$ minute & 28 & 23.30 \\
\hline Focal with awake & 10 & 8.30 \\
\hline Focal without awake & 22 & 18.30 \\
\hline Atonic & 2 & 1.60 \\
\hline Total & 120 & 100 \\
\hline
\end{tabular}

Table-5: CSF Indices in cases with complex febrile seizures (CFS) in different age groups.

\begin{tabular}{|l|l|l|l|l|l|}
\hline Variable & $\begin{array}{c}\text { WBC } \\
>5 / \mathrm{mm} 3\end{array}$ & $\begin{array}{c}\text { PMN } \\
>5 / \mathrm{mm} 3\end{array}$ & $\begin{array}{c}\text { Pus cell } \\
\geq 2 / \mathrm{mm} 3\end{array}$ & $\begin{array}{c}\text { Mean } \\
\text { Glucose } \\
\text { levels }\end{array}$ & $\begin{array}{c}\text { Mean } \\
\text { Protein } \\
\text { level }\end{array}$ \\
\hline $\begin{array}{l}6-12 \\
\text { months } \\
(63)\end{array}$ & 12 & 9 & 3 & $56 \pm 4.3$ & $49 \pm 3.8$ \\
\hline $\begin{array}{l}12-24 \\
\text { months(32) }\end{array}$ & 9 & 3 & 0 & $47 \pm 3.8$ & $45 \pm 2.6$ \\
\hline $\begin{array}{l}24-60 \\
\text { months } \\
(25)\end{array}$ & 8 & 2 & 1 & $46 \pm 1.2$ & $38 \pm 2.4$ \\
\hline
\end{tabular}

CSF examination was done in all the 120 cases. Among them raised WBC count (more than $5 / \mathrm{mm} 3$ ) was seen in 29 cases while pus cells were observed in 4 cases and these all were treated as meningitis. Mean (SD) glucose levels were $56 \pm 4.3$ found in the age group of 6 to 12 months (Table 5).

\section{Discussion}

The younger the patient, the more was the risk of the complex febrile seizure. In the present study, it was found a total of 63 children in 6-12 months age, 32 in 12-24 months. Likewise, Nadirah Rasyid Ridha et.al [10], in their study, revealed that $48 \%$ of children having CFS were within 18 months of age. A study by Berg AT et.al [11], showing that $57 \%$ of children with complex Febrile Seizures were less than 18 months old.

Other studies have also come to the same conclusion $[12,13,14]$. Therefore, younger the age more is the chance that a child presenting with fever and seizure may have a complex febrile seizure.

Meningitis is a medical emergency in children and should not be missed in any children with fever with seizures. Among the 120 cases, 23 had meningitis
Showing that almost one-sixth of children presenting in the emergency room with complex febrile seizures have meningitis. Out of a total of 120 cases, $55(45.8 \%)$ were having impaired consciousness. Azita Tavasoli et al [16] observed that all patients with Bacterial meningitis had complex FS. Impaired consciousness was seen in 15 cases with meningitis (78.9\%) and 6 cases with bacterial meningitis (85.7\%) compared with 26 cases with a normal LP (6.5\%) similarly in the present study all patients with bacterial meningitis had impaired consciousness.

In this study, among children with complex FS, $32(26.6 \%)$ and $06(5 \%)$ cases had a positive family history of the first degree and second relative respectively. In the meta-analysis by Offringa et al [17], $43 \%$ of children with FS had a positive family history $\left(1^{\circ}\right.$ relative) and $32 \%$, without a family history. Berg et al [18] found that $36 \%$ of children with a positive family history had recurrence at one year and $20 \%$, without a family history. Ausi Indriani et al [19], in their study, revealed that family history was positive in only $28 \%$ of patients with recurrent $\mathrm{FS}$ and negative in $57 \%$ of patients. Hence, a family history of febrile seizures is associated with CFS.

During the study, it was observed that the most common cause attributed to CFS was Upper Respiratory Tract Infection (URTI) in 54 cases $(45 \%)$, followed by Meningitis/encephalitis in 23 cases $(19.20 \%$ ) (Table 3 ). Ciftci $M$ et al [20] also found similar results as URTI being the most common cause attributed to CFS in $36 \%$ patients followed by lower respiratory tract infections (18\%) followed by acute gastroenteritis (15\%). So proper and timely attention is required in children having URI with fever.

In this study, it was found that 86 cases were having Generalized tonic-clonic seizures. Among them, in 58 cases it was of more than 15 minutes duration. Haim Bassan et al [21] found that $43 \%$ of CFS patients had Generalized tonic-clonic seizures with a time duration of more than 15 minutes.

In this study, the CSF examination was performed in all the 120 cases. Among them raised WBC count (more than $5 / \mathrm{mm} 3$ ) was seen in 29 cases while pus cells were observed in 4 cases and these all were treated as meningitis. Lisa G. Rider et al [22] found WBC count more than $5 / \mathrm{mm} 3$ in $9.8 \%$ in children 2- 24 months of age. Thus, CSF examination is a helpful diagnostic tool both in finalizing diagnosis 
And treatment.

\section{Limitations}

The main limitation of this study was that it was a single hospital-based study. Hence, metacentric and community-based studies are needed to generalize the results in the general population. The other limitation was that the parents may not have been able to give us an accurate past history of whether they had seizures as children.

\section{Conclusion}

In conclusion, it was found that age less than 1 year and male gender were the most significant risk factors for Complex Febrile Seizure in our area. Meningitis is a common presentation in the emergency and in cases of complex febrile seizure, meningitis should always be considered as a differential diagnosis. Lumbar puncture is necessary for the differential diagnosis in all CFS cases to rule out meningitis, even in the absence of meningeal signs.

\section{What study adds to existing knowledge?}

Complex Febrile Seizures in children are a common indication for the hospital admission. Early detection of the cause and accordingly the start of appropriate treatment is the basic pillar. CSF examination plays a significant role in early diagnosis in these cases. Children with CFS should be on regular long term follow up and treatment. This knowledge will facilitate the diagnosis, early educational intervention, and multidisciplinary therapeutic approaches.

\section{Author's contribution}

Dr. Mugdha Paranjape, Dr. Amit Patil, Dr. Sachin Bodhgire: Data Collection, ethical approval.

Dr. Amol Suryavanshi, Dr. Shilpa Pawar, Dr.

Rahul Anerao: Data analysis, manuscript writing.

\section{Reference}

01. Hom J, Medwid K. The low rate of bacterial meningitis in children, ages 6 to 18 months, with simple febrile seizures. Acad Emerg Med. 2011;18(11)1114-1120.

doi: $10.1111 / \mathrm{j} .1553-2712.2011 .01216 . x$ [Crossref]
02. Chin RFM, Neville BGR, Scott RC. Meningitis is a common cause of convulsive status epilepticus with fever. Arch Dis Child. 2005;90(1)66-69. doi: 10.1136/adc.2003.038844 [Crossref]

03. Johnston MV. Seizures in childhood In- Behrman RE, Kliegman RM, Jenson HB, editors. Nelson textbook Pediatrics, 17th ed, Saunders press. 2004; 1993-1994.

[Crossref]

04. Kimia A, Ben-Joseph EP, Rudloe T, Capraro A, Sarco D, Hummel $D$, et al. Yield of lumbar puncture among children who present with their first complex febrile seizure. Pediatr. 2010;126(1)62-69.

doi: 10.1542/peds.2009-2741 [Crossref]

05. Subcommittee on Febrile Seizures. Febrile seizures- Guidelines for the neurodiagnostic evaluation of the child with a simple febrile seizure. Pediatr. 2011;127(2)389-394.

doi: $10.1542 /$ peds.2010-3318 [Crossref]

06. Trainor JL, Hampers LC, Krug SE, Listernick R. Children with first-time simple febrile seizures are at low risk of serious bacterial illness. Acad Emerg Med. 2001;8(8)781-787.

doi: $10.1111 / \mathrm{j} .553-2712.2001 . t b 00207 . x$ [Crossref]

07. Akpede GO, Sykes RM, Abiodun PO. Indication for lumbar puncture in children presenting with convulsions and fever of acute onsetexperience in the children's emergency room of the University of Benin Teaching Hospital, Nigeria. Ann Trop Paediatr. 1992;12(4)385-389. doi: 10.1080/02724936.1992.11747603 [Crossref]

08. Casasoprana A, Hachon LC, Claudet I, Grouteau $E$, Chaix $Y$, Cances $C$, et al. Value of lumbar puncture after a first febrile seizure in children aged less than 18 months. Arch Pediatr. $2013 ; 20(6) 594$.

doi: $10.1016 /$ j.arcped.2013.03.022 [Crossref]

09. Akpede GO, Sykes RM. Convulsions with fever as a presenting feature of bacterial meningitis among preschool children in developing countries. Dev Med Child Neurol. 1992;34(6)524-529.

doi: $10.1111 /$ j.1469-8749.1992.tb11473.x [Crossref] 
10. Haslam RHA. Neurological evaluation. InBehrman RE, Kliegman RM, Jenson HB, editors. Nelson textbook of pediatrics, 17 th edSaunders press.

2004;1980-1981 [Crossref]

11. Ridha NR, Nara $P$, Angriani $H$, Daud D. Identification of risk factors for recurrent febrile convulsion. Paediatr Indones. 2009;49(2)87-90. doi: $10.14238 /$ pi49.2.2009.87-9 [Crossref]

12. Berg AT, Shinnar S, Hauser WA. A prospective study of recurrent febrile seizures. N Engl J Med. $1992 ; 327(16) 1122-1127$.

doi: 10.1056/NEJM199210153271603 [Crossref]

13. Ausi Indriani, Nelly Amalia Risan, Titing Nurhayati. Five Years Study of Recurrent Febrile Seizure Risk Factors. AMJ. 2017;4(2)282-285. doi: 10.15850/amj.v4n2.1086 [Crossref]

14. Laditan AA. Analysis of the results of routine lumbar puncture after a first febrile convulsion in Hofuf, Al- Hassa, Saudi Arabia. East Afr Med J. $1995 ; 72(6) 376-378$.

doi: $10.3126 /$ bjhs.v3i2.20933 [Crossref]

15. Offringa $M$, Bossuyt PMM, Lubsen J, Ellenberg $\mathrm{JH}$, Nelson KB, Knudsen FU, et al. Risk factors for seizure recurrence in children with febrile seizures- A pooled analysis of individual patient data from five studies. J Pediatr. 1994; 124(4)574-584.

doi: $10.1016 /$ S0387-7604(96)00059-9 [Crossref]
16. Jaffe M, Bar-Joseph G, Tirosh E. Fever and convulsions - indications for laboratory investigations. Paediatr. 1981;67(5)729-731. [Crossref]

17. Abuekteish F, Daoud AS, Al-sheyyab M, Nou'man M. Demographic characteristics and risk factors of first febrile seizures- a Jordanian experience. Trop Doct. 2000;30(1)25-27. doi: $10.1177 / 004947550003000113$ [Crossref]

18. Tavasoli A, Afsharkhas L, Edraki A. Frequency of Meningitis in Children Presenting with Febrile Seizures at Ali-Asghar Children's Hospital. Iranian journal of child neurology. 2014;8(4)51. doi: $10.22037 /$ ijcn.v8i4.6069 [Crossref]

19. Berg AT, Shinnar S, Darefsky AS, Holford TR, Shapiro ED, Salomon ME, et al. Predictors of recurrent febrile seizures- a prospective cohort study. Arch Pediatr Adolesc Med. 1997;151(4)371-378.

doi: $\quad 10.1001 /$ archpedi.1997.02170410045006 [Crossref]

20. Ciftci M, Erdogan F, Nuhoglu C, Ceran O. Lumbar Puncture Findings in İnants under 12 Months of Age with Simple Febrile Seizure. ARC Journal of Pediatrics. Volume 2, Issue 2, 2016, PP 9-13.

doi: 10.20431/2455-5711.0202002 [Crossref]

21. Bassan H, Barzilay M, Shinnar S, Shorer Z, Matoth I, Gross-Tsur V. Prolonged febrile seizures, clinical characteristics, and acute management. Epilepsia. 2013;54(6)1092-1098. doi: $\quad 10.1007 / \mathrm{s} 13312-020-1759-0 \quad$ [Crossref] 